\title{
Impacts of water resource planning on regional water consumption pattern: A case study in Dunhuang Oasis, China
}

\author{
ZHANG Xifeng ${ }^{1}$, JIN Xin ${ }^{2}$, BAI Xiao ${ }^{2}$, JIANG Yanbin ${ }^{1}$, HE Chansheng ${ }^{2,3 *}$ \\ ${ }^{1}$ College of Resource and Environment, Huazhong Agricultural University, Wuhan 430070, China; \\ ${ }^{2}$ Key Laboratory of West China's Environmental System (Ministry of Education), College of Environment and Earth Science, \\ Lanzhou University, Lanzhou 730000, China; \\ ${ }^{3}$ Department of Geography, Western Michigan University, Kalamazoo MI 49008-5200, USA
}

\begin{abstract}
Water resources are critical for the existence and development of oases in endorheic basins. Thus, to enable sustainable development, it is fundamentally important to understand how to allocate and use these resources in a reasonable way. We therefore simulated and analyzed changes in water consumption pattern within the Dunhuang Oasis of China under three scenarios using a system dynamic model that corresponds to different water consumption pattern. This was done to assess the impacts of regional water resource planning (comprehensive planning of the rational use of water resource and protection of ecosystem services in the Dunhuang Basin) on water consumption pattern within the Dunhuang Oasis. The first of these, Scenario 1, is a baseline in which the status quo is maintained, while Scenario 2 incorporates the comprehensive effects of agricultural water-saving irrigation measures with an inter-basin water diversion project, and Scenario 3 focuses on ecological rehabilitation. In the baseline Scenario 1, the total water consumption within the Dunhuang Oasis increased progressively while agricultural water consumption remained extremely high and threatened overall ecological security. In contrast, Scenario 2 would decrease agricultural water consumption by almost $5.30 \times 10^{7} \mathrm{~m}^{3}$ following the implementation of water-saving practices. The additional water allocated from an inter-basin water diversion project would play an important role in alleviating ecological strain on the oasis. Finally, in Scenario 3, the total irrigated land must be decreased to $20.6 \times 10^{3} \mathrm{hm}^{2}$ by 2025 assuming that water supply for ecosystem restoration would be at least $50 \%$ of the total consumption. Although water resource planning plays a very important role in alleviating the ecological water crisis within the oasis, it is necessary to consider the suitable scale of oasis with regard to current water consumption pattern.
\end{abstract}

Keywords: water resources planning; water consumption pattern; system dynamics model; ecological rehabilitation; Dunhuang Oasis

Citation: ZHANG Xifeng, JIN Xin, BAI Xiao, JIANG Yanbin, HE Chansheng. 2019. Impacts of water resources planning on regional water consumption pattern: A case study in Dunhuang Oasis. Journal of Arid Land, 11(5): 713-728. https://doi.org/10.1007/s40333-019-0092-8

\section{Introduction}

Arid and semi-arid regions cover more than $30 \%$ of the Earth's land surface (Okin et al., 2006) and $22 \%$ of land area in China (Hu et al., 2010). An oasis is defined as a specific landscape that exists

\footnotetext{
*Corresponding author: HE Chansheng (E-mail: cshe@1zu.edu.cn)

Received 2018-06-11; revised 2019-01-25; accepted 2019-04-23

(C) Xinjiang Institute of Ecology and Geography, Chinese Academy of Sciences, Science Press and Springer-Verlag GmbH Germany, part of Springer Nature 2019
} 
within deserts in arid and semi-arid regions and that enables flourishing vegetation and human settlement because of a stable water supply (Ling et al., 2013). Without water, an oasis cannot survive and will become desertified; this coupled relationship between an oasis and water is determined by basic water resource patterns. For a catchment in arid region, the upper reaches is the water production area with snow and glacier melting from mountains; and the middle and lower reaches are the water consumption area with scarce precipitation. Enhanced water consumption in the upper and middle reaches caused by the booming population and rapid economic development results in more serious ecological problems in the corresponding lower reaches (Cheng et al., 2014). These effects include the desiccation of terminal lakes, increased sandstorms and the death of Populus euphratica forests leading to a series of severe ecological disasters (Department of Geoscience, Chinese Academy of Sciences, 1996). The world heritage sites of Mogao Grottoes, Mingsha Mountain (sounding dunes), and Crescent Spring all are located within the Dunhuang Oasis of China (Zhang et al., 2014). The water resource crisis in this region is therefore a threat to this natural oasis as well as the precious cultural heritage.

The rapid development of intensive agriculture alongside an increase in human activity, especially production expansion and the modification of irrigation channels in the middle reaches, have substantially modified the catchment hydrological cycle and have negative impacts on ecosystem sustainability within the lower reaches (Qi and Luo, 2006; de Fraiture et al., 2010). Therefore, the main problem is the competition in water demands between the developments of socio-economy and sustainable ecosystem within inland river basins (Micklin, 1988; Feng et al., 2001). A huge range of water resource planning strategies have therefore been implemented to address this issue within inland river basins around the world, including the Tarim River Basin (Sun et al., 2011), Heihe River Basin (Cheng et al., 2014; Hu et al., 2015a), and Shiyang River Basin in China (Zhu and Li, 2014), the Murray-Darling River Basin (MDB) in Australia (Wheeler et al., 2014) and the Guadalquivir River Basin in Spain (Berbel et al., 2015).

The MDB Plan is an example of an early water resource planning strategy that was introduced in 1914 to develop the River Murray Waters Agreement following several years of droughts, debates and community actions to address water shortages (Crase et al., 2004; Woodhouse et al., 2006; Burke, 2012). The MDB Plan was finally signed into law in December 2012 (Zhao et al., 2015) and has since had a marked effect on recovering ecosystem functions and balancing the multiple needs within this basin (Bark et al., 2013). The most advanced water resource planning strategy currently in place in Europe is the case of the Guadalquivir River in Spain; this waterway is the largest river in southern Spain and crosses $25 \%$ of the nation's irrigated area. The Guadalquivir River Basin has reached its extraction limit, however, and has no additional water sources available in this region. A consequent reduction in water use is therefore planned across this basin, including water-saving measures to be applied in both agricultural and urban sectors. This plan represents a useful strategy to achieve sustainable water management because it details economic and technical measures to control demand while fulfilling wastewater treatment objectives including non-point source pollution from agriculture as well as urban point source pollution (Gutiérrez-Martín et al., 2017). The first successful water resource planning case within China has been the Heihe River Basin Plan (Cheng et al., 2014). The Heihe River Basin is the second largest inland river basin within the northwestern China. Excessive water consumption due to agriculture production has impacted artificial oases in the middle reaches, and the Ejin Oasis in the lower reaches has experienced increasingly serious ecological problems. An ecological water diversion project was therefore implemented at the end of the $20^{\text {th }}$ century and severe ecosystem deterioration in the lower reaches has been dramatically mitigated (Cheng et al., 2014). The middle reaches of this basin are required to transfer $9.50 \times 10^{8} \mathrm{~m}^{3}$ of water to the lower reaches in "normal" years (defined as a year in which the upper reaches of the basin discharge $15.80 \times 10^{8} \mathrm{~m}^{3}$ of water) (Hu et al., 2015b). This increased water volume is then allowed to flow into the lower reaches of the basin restoring lakes and supporting the recovery of vegetation within the Ejin Oasis (Hu et al., 2015a).

The focus of this analysis is the Dunhuang Oasis, which is adjacent to the Heihe River Basin. 
This oasis has experienced competitive water pressures between economy and ecosystem, which is similar to that of Heihe River Basin. The Danghe River has a total volume of $4.63 \times 10^{8} \mathrm{~m}^{3}$ and is the largest watercourse within the Dunhuang Oasis. The water resource exploitation and utilization rates are close to $100 \%$ in the oasis and the agricultural water consumption accounts for nearly $90 \%$ of total resource available. Ecological water use over recent decades has been impacted by the rapid development of the local economy. This has led to an ecological crisis mainly manifest in a shrunken terminal lake, a decline in the groundwater level and accelerated desertification. Water has become both the primary restrictive factor and bottleneck for socioeconomic development within the Dunhuang Oasis. Thus, in order to protect precious local heritage and improve the ecological environment, Dunhuang City has proposed a program of "Comprehensive Planning of the Rational Use of Water Resource and Protection of Ecosystem Services in the Dunhuang Basin" (DBP) (Water Resource Department of Gansu Province, 2011). Programs proposed within the DBP include agricultural water-saving measures, patterns of crop and industrial structural adjustments, as well as a water transfer project from the Sugan Lake Basin to the Danghe River Basin. The 2020 goals of the DBP are to: (1) maintain groundwater in an equilibrium state; (2) raise the water level of Crescent Lake to $2 \mathrm{~m}$ to recover its original shape; (3) stop the expansion of desertification within the basin and grassland degeneration around the oasis fringes; and (4) maintain the West Lake Nature Reserve in a stable state. Scenario 2 and Scenario 3 in this study are based on the DBP. We also extended the simulation period assessed here from 2020 to 2025 to encompass the extra time necessary to implement this plan.

This study therefore emphasized the DBP that aims to simulate future water consumption patterns under three scenarios. Baseline Scenario 1 is based on the situation at present, Scenario 2 is formulated according to the DBP framework, and Scenario 3 incorporates ecological recovery. Analysis and comparison of these three scenarios provide a partial basis for policy making across this area as well as other dryland regions. This is important because the ecological problem of Dunhuang Oasis is not isolated but is common in other inland river basins as well as arid regions globally (Niu et al., 2010; Zhang et al., 2014).

\section{Study area}

The Dunhuang Oasis $\left(40^{\circ} 02^{\prime}-40^{\circ} 28^{\prime} \mathrm{N}, 94^{\circ} 31^{\prime}-94^{\circ} 55^{\prime} \mathrm{E}\right)$ is bounded by West Lake Wetland to the west and Danghe River Reservoir to the south (Fig. 1). The elevation of this region is between 80 and $1650 \mathrm{~m}$ a.s.l. As this area is far inland, a dry climate with low precipitation is typical. Based on data collected from 1954 to 2014 by Dunhuang Meteorological Station, the annual mean temperature within this area is $9.6^{\circ} \mathrm{C}$ with recorded maximum and minimum temperatures of $43.6^{\circ} \mathrm{C}$ in July and $-28.6^{\circ} \mathrm{C}$ in January, respectively. Although the mean annual precipitation is only $39.2 \mathrm{~mm}$, the mean annual potential evaporation can reach $2486.0 \mathrm{~mm}$. Precipitation is concentrated between April and September in this area, the average relative humidity is less than $40 \%$ and the annual solar radiation is $6418.4 \mathrm{MJ} / \mathrm{m}^{2}$.

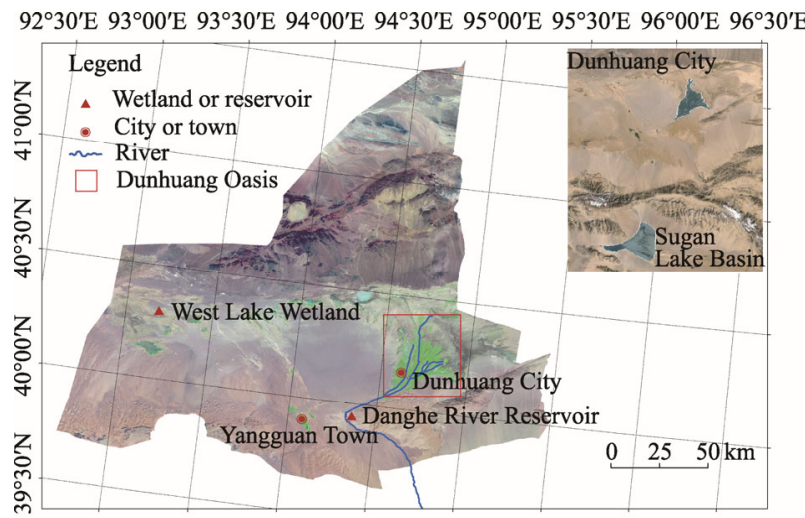

Fig. 1 Location of the study area derived by Landsat TM image (Bands 5-4-2) 


\section{Methods}

The system dynamics (SD) approach was first proposed by J.W. Forrester who is known as the founder of SD. This method describes system structures using stocks, flows and internal feedback loop functions in diagrams to simulate dynamic behavior (Forrester, 1961). A SD model can therefore be used to describe linkages among system components at different levels and can also illustrate dynamic feedback processes. The SD model can also be used to predict changes in complex systems under "what-if" scenarios and can therefore be very useful for examining and recommending policy decisions in management and social contexts (Mohapatra et al., 1994). The SD methodology has been applied across numerous research fields including urban and ecoenvironmental planning as well as for the evaluation of land carrying capacity (Higgins et al., 1997; Gertseva et al., 2004; Huang et al., 2009). In this study, we established, tested and simulated water consumption pattern (WCP) under three scenarios using the SD model.

\subsection{SD model components}

On the basis of the relationship between variables and feedback structure, we determined a causality diagram and a flow chart (Fig. 2) and then used the software Vensim PLE SD (Ventana System, Inc. USA) to design a model. Under WCP, water supply comprises surface water, groundwater exploitation and upcoming inter-basin water diversions while consumption includes agricultural, domestic, industrial, service and ecological components. We simplified this model into four subsystems comprising water resource, population-livestock, economic and ecological components. The "what-if" scenario assumption applied here as well as the causal relationships between individual subsystems are described in more detail in subsequent sections.

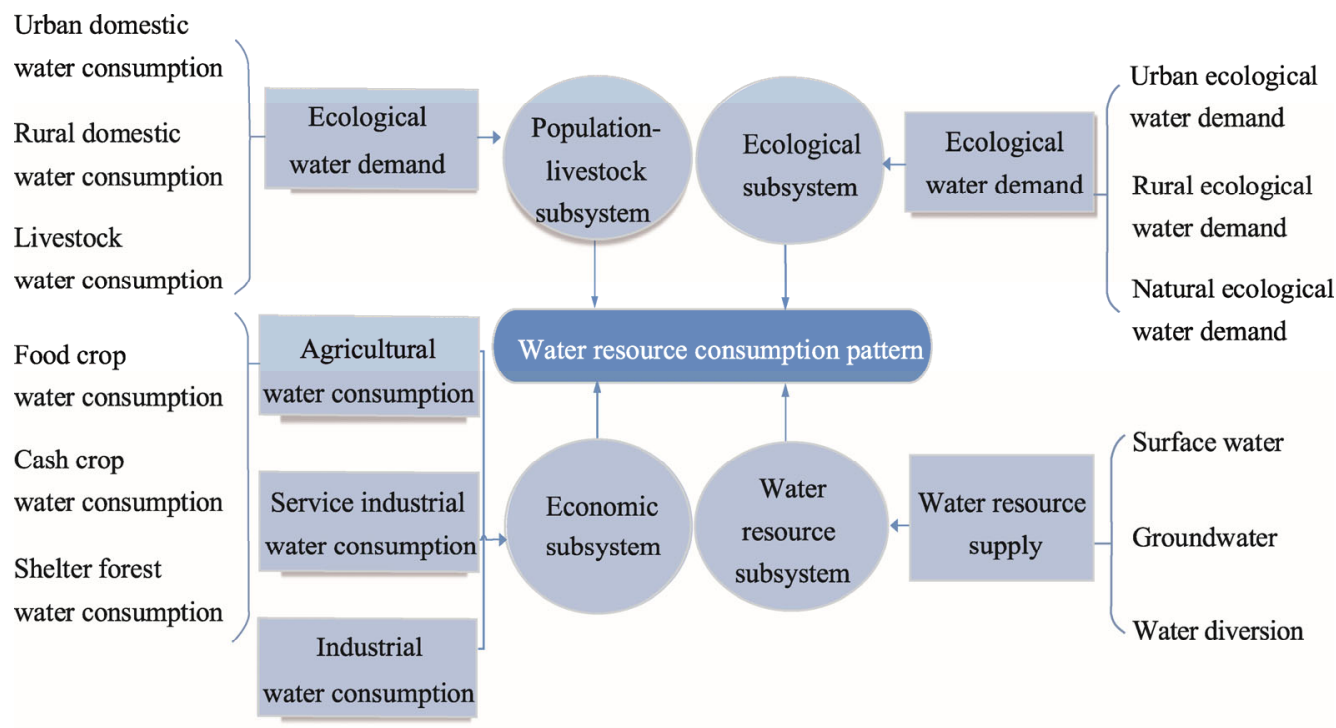

Fig. 2 Components of the water consumption pattern (WCP) in Dunhuang Oasis

\subsubsection{Water resource subsystem}

Surface and groundwater are the most important components that comprise the water resource subsystem within the study area (Fig. 3). Indeed, when the Sugan Lake Basin water diversion project is completed, the Dunhuang Oasis will receive an additional volume of water about $8.35 \times 10^{7} \mathrm{~m}^{3}$. To simplify this model, water supplied from this project was assumed to be zero prior to 2020 and to then remain at a constant volume of $8.35 \times 10^{7} \mathrm{~m}^{3}$ between 2021 and 2025 . The diversion project aims to recover the ecological conditions of both the Crescent Spring and West Lake Wetland and to ease the severe groundwater depletion of Dunhuang Oasis. 


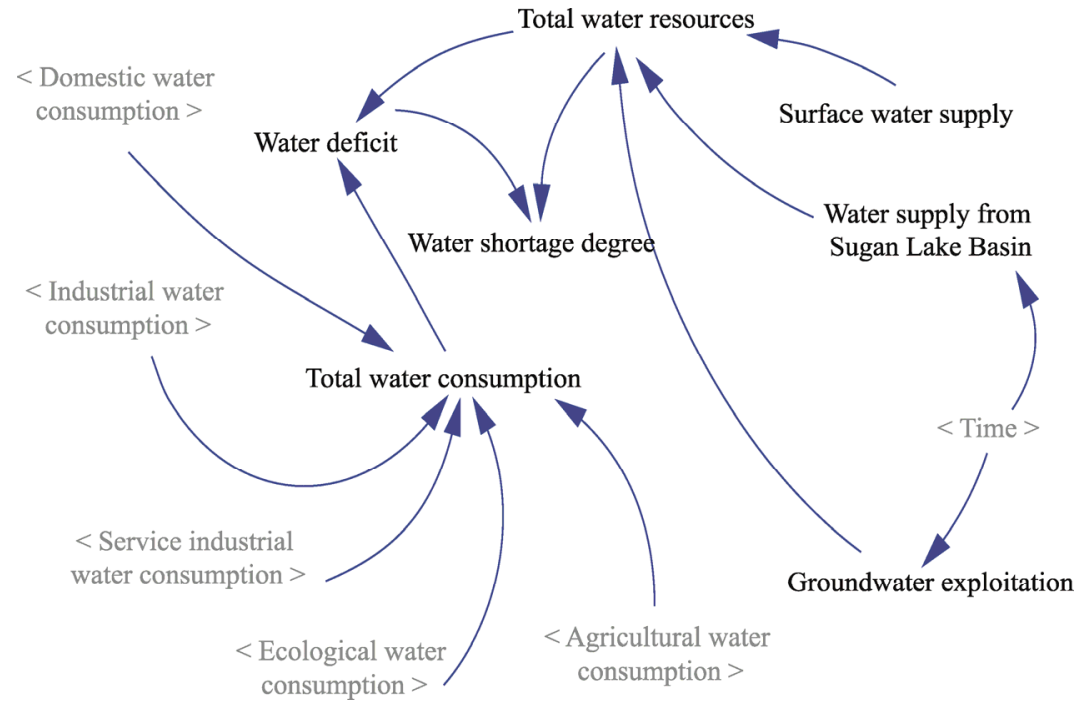

Fig. 3 Water resource subsystem in Dunhuang Oasis

\subsubsection{Population-livestock subsystem}

The primary domestic water consumer in this case is the population-livestock subsystem. This subsystem comprises urban domestic, rural domestic and livestock water consumption (Fig. 4). Specific variables and their relationships to one another are listed in Tables 1-6. The feedback of the population-livestock subsystem is reflected by the annual increase rate of water demand and the shortage of water available (Fig. 5).

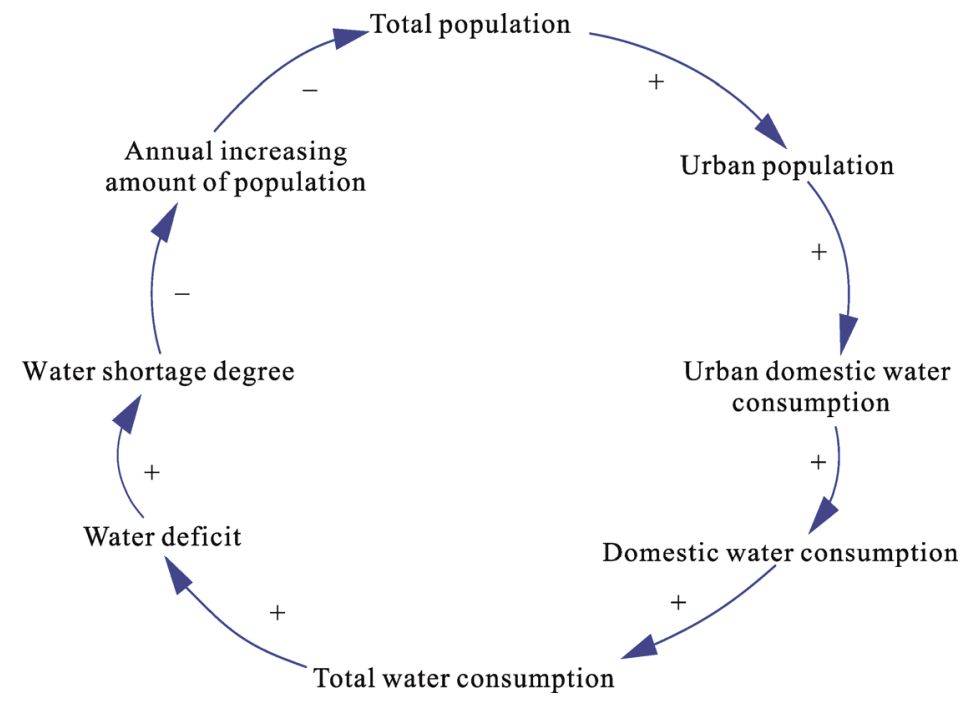

Fig. 4 Population-livestock subsystem in Dunhuang Oasis. "+" that means the latter increases as the former increases or the latter decreases as the former decreases, which is defined as positive feedback. "-" means that the latter increases as the former decreases or the latter decreases as the former increases, which is defined as negative feedback.

\subsubsection{Economic subsystem}

The economic subsystem in this case comprises industrial, service industrial and agricultural water consumption. Industrial and service industrial water consumption volumes are influenced by corresponding industrial outputs, technological processes and water use efficiencies (Fig. 6).

Agricultural water consumption is influenced by the changes in total irrigated area, crop patterns and water-saving practices (Fig. 7). Thus, considering that the DBP is feasible, this study assumes 


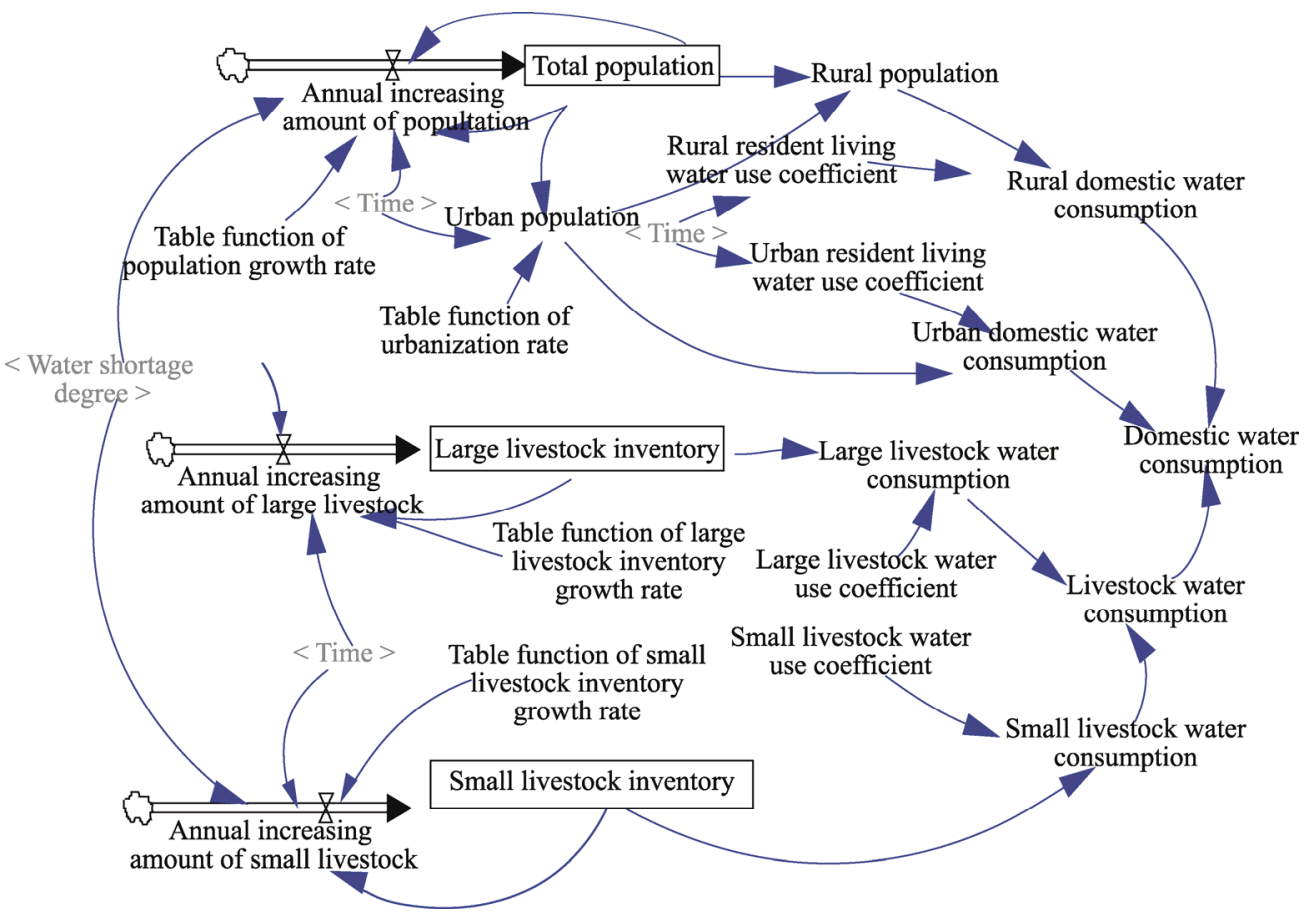

Fig. 5 Population-livestock subsystem loop

that: (1) irrigated area will decrease gradually by $3600 \mathrm{hm}^{2}$ until 2025; (2) high ecological value cash crops (i.e., grapes, fruit trees) will be developed while the number of food crops (i.e., spring wheat, corn) will be decreased; (3) irrigation efficiency will be improved by increasing microirrigation, canal micro-irrigation and greenhouse micro-irrigation areas to ensure that the entire Dunhuang Oasis becomes a water-saving region. These measurements aim to decrease net agricultural water consumption, replenish the growing domestic-industrial water demand and ultimately alleviate groundwater depletion.

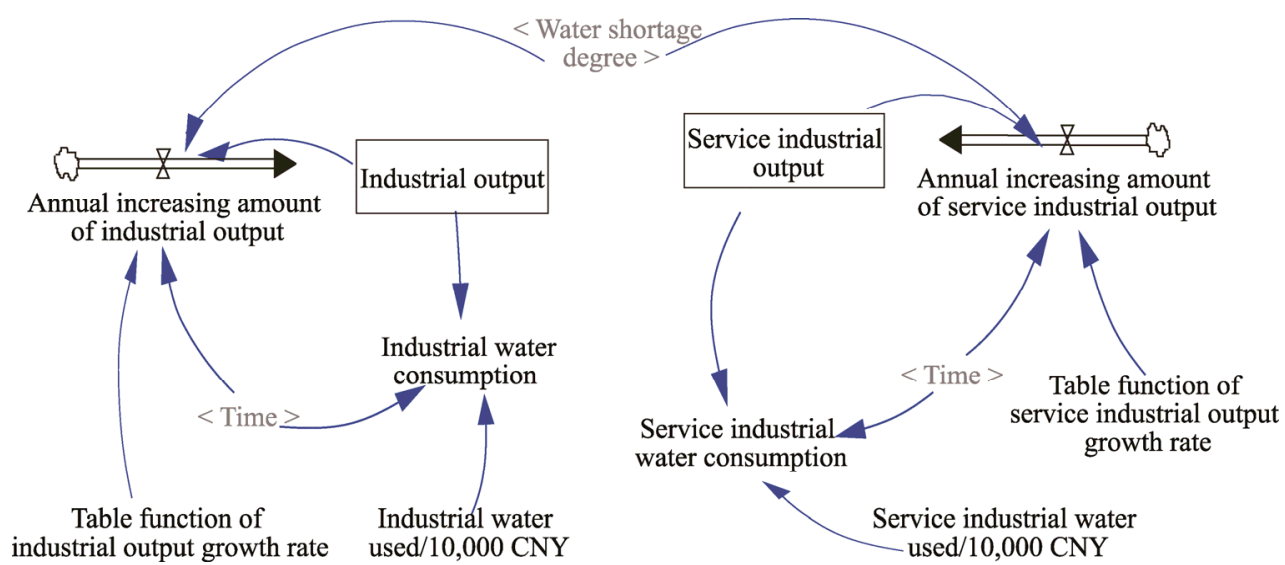

Fig. 6 Industrial and service industrial subsystems in Dunhuang Oasis

\subsubsection{Ecological subsystem}

Ecological water demand comprises urban and rural ecological water demand as well as ecological water discharge and the Crescent Spring ecological water supplement (Fig. 8). Urban ecological water demand includes the water requirements of urban public green and lake areas as well as urban roads. Rural ecological water demand, in contrast, primarily consists of the wind break forest system water requirement, while ecological withdrawal denotes the amount of water released 
directly from the Danghe River Reservoir. The Crescent Spring is a world famous natural landscape that also requires a certain amount of water to maintain a stable water level.

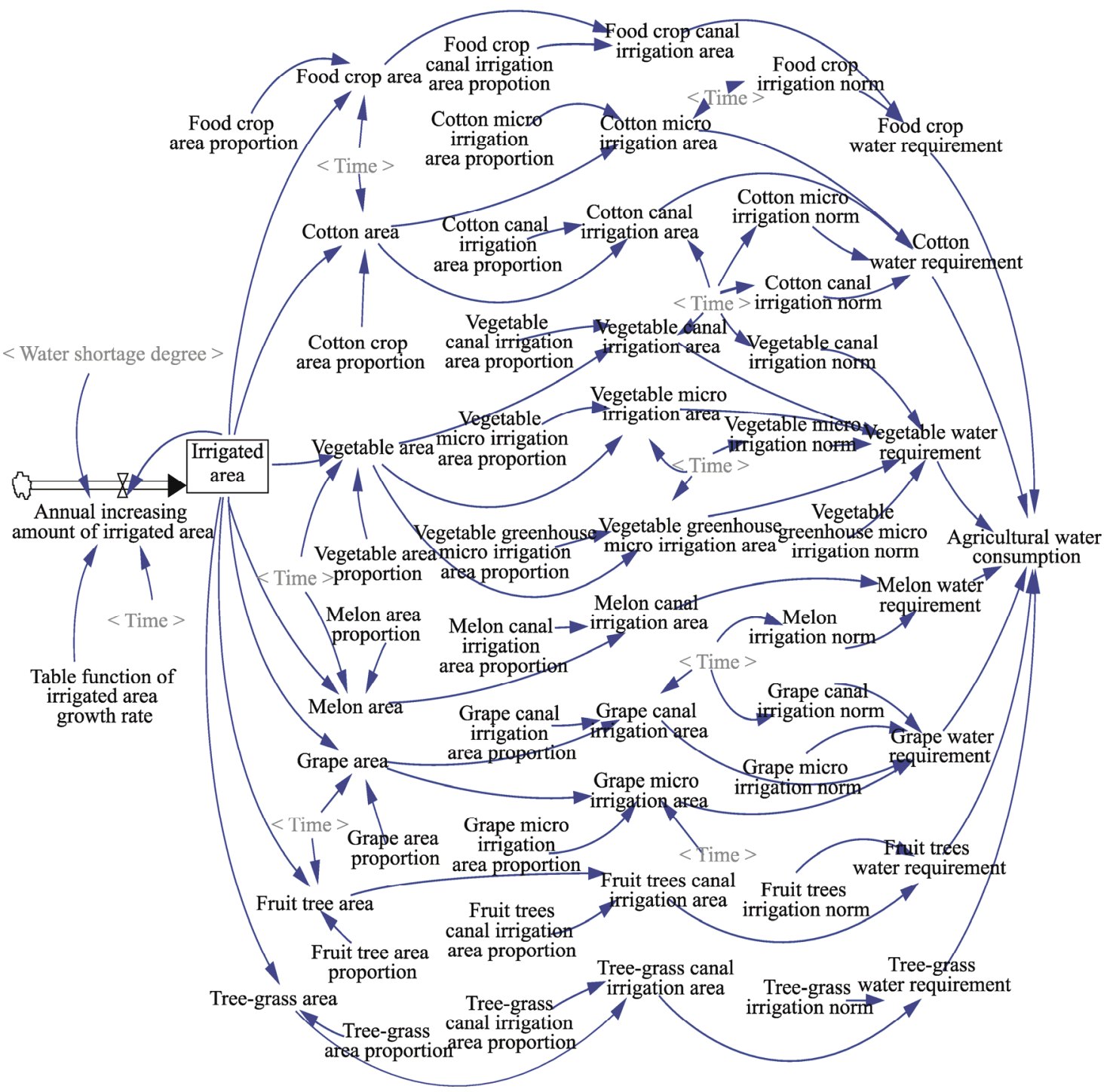

Fig. 7 Agricultural subsystem in Dunhuang Oasis

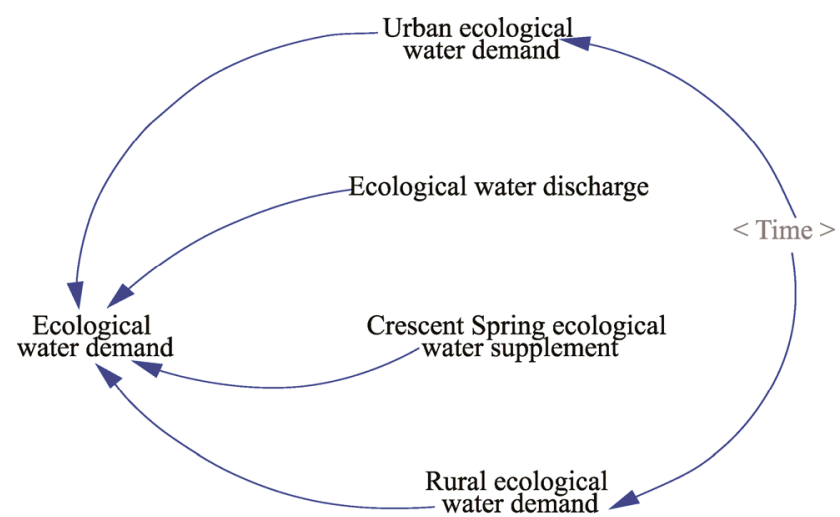

Fig. 8 Ecological subsystem in Dunhuang Oasis 


\subsection{Data}

The data used in this study include observation records between 1990 and 2010 obtained from the Dunhuang Meteorological Station as well as population and industrial records extracted from the Dunhuang National Ecological Statistics Yearbook (Bureau of Statistics of the City of Dunhuang, 2007, 2013), water use quota data extracted from industrial water use records for Gansu Province (Water Resources Department of Gansu Province, 2005), from the field water-saving transformation project preliminary design report of the Danghe River irrigation district (Gansu Province Water Conservancy and Hydropower Investigation and Design Institute, 2011), and water resource planning data extracted from comprehensive plans for the rational use and protection of ecosystem services within the Dunhuang Basin (Water Resource Department of Gansu Province, 2011). These data were used to calculate the service industrial, industrial and agricultural water consumptions as well as the ecological water demand. The statistical data used in this study did not include that of Yanguan Town.

The specific equations and variables included within the model utilized here are summarized in Table 1; this summary presents the partial logic relationship between domestic and agricultural water consumption, as all other subsystems exhibit a similar relationship. Records in Tables $2-4$ include initial values and table function values and "if then else" functions.

Table 1 Logical relationships among variables

\begin{tabular}{|c|c|c|c|}
\hline System item & Variable & Code & Logical relationship \\
\hline Domestic & Total population & 11 & $11=\operatorname{INTEG}(12,11)$ \\
\hline water & Annual increasing amount of population & 12 & $12=11 \times \mathrm{T} 1 \times(\mathrm{a}+\mathrm{b} \times 17 / \mathrm{c})$ \\
\hline \multirow[t]{9}{*}{ consumption } & Population growth rate & $\mathrm{T} 1$ & - \\
\hline & Urban population & 13 & $13=11 \times \mathrm{T} 1$ \\
\hline & Urbanization rate & $\mathrm{T} 2$ & - \\
\hline & Rural population & 14 & $14=11-13$ \\
\hline & Rural residents living water-use coefficient & $\mathrm{F} 1$ & - \\
\hline & Urban residents living water-use coefficient & F2 & - \\
\hline & Rural domestic water consumption & 15 & $15=14 \times \mathrm{F} 1$ \\
\hline & Urban domestic water consumption & 16 & $16=13 \times \mathrm{F} 2$ \\
\hline & Water shortage degree & 17 & - \\
\hline \multirow{10}{*}{$\begin{array}{l}\text { Agricultural } \\
\text { water } \\
\text { consumption }\end{array}$} & Irrigated area & 21 & - \\
\hline & Cotton area & 22 & $22=21 \times \mathrm{T} 3$ \\
\hline & Cotton area proportion & $\mathrm{T} 3$ & - \\
\hline & Cotton canal irrigation area & 23 & $23=22 \times \mathrm{T} 4$ \\
\hline & Cotton micro-irrigation area & 24 & $24=22 \times \mathrm{T} 5$ \\
\hline & Cotton canal irrigation area proportion & $\mathrm{T} 4$ & - \\
\hline & Cotton micro irrigation area proportion & $\mathrm{T} 5$ & - \\
\hline & Cotton canal irrigation norm & $\mathrm{F} 3$ & - \\
\hline & Cotton micro irrigation norm & $\mathrm{F} 4$ & - \\
\hline & Cotton water requirement & 25 & $25=23 \times \mathrm{F} 3+24 \times \mathrm{F} 4$ \\
\hline
\end{tabular}

Note: $\mathrm{T}$ denotes a variable that is a table function; F marks a variable that is a "if then else" function. INTEG, integral; -, no logical relationship with other variables: $a=1 ; b=2 ; c=100$.

Table 2 Table function values

\begin{tabular}{lcrrrrrrr}
\hline Variable & $1990-2020$ & 1990 & 1995 & 2000 & 2005 & 2010 & 2015 & 2020 \\
\hline $\begin{array}{l}\text { Urbanization rate } \\
\begin{array}{l}\text { Service-industrial water used } \\
\left(\times 10^{4} \mathrm{CNY}\right)\end{array}\end{array}$ & $-0.006-1.000$ & 0.195 & 0.255 & 0.436 & 0.487 & 0.510 & 0.592 & 0.649 \\
$\begin{array}{l}\text { Cotton canal irrigation area } \\
\text { proportion }\end{array}$ & $9.000-25.000$ & 25.000 & 22.000 & 20.000 & 18.000 & 14.500 & 11.300 & 9.300 \\
\hline
\end{tabular}


Table 3 Initial values

\begin{tabular}{lc}
\hline \multicolumn{1}{c}{ Variable } & Initial value \\
\hline Total population $\left(\times 10^{4}\right)$ & 10.99 \\
Large livestock inventory $\left(\times 10^{4}\right)$ & 2.38 \\
Small livestock inventory $\left(\times 10^{4}\right)$ & 48.08 \\
Industrial output $\left(\times 10^{7} \mathrm{CNY}\right)$ & 3.28 \\
Service industrial output $\left(\times 10^{7} \mathrm{CNY}\right)$ & 6.04 \\
Irrigated area $\left(\times 10^{4} \mathrm{hm}^{2}\right)$ & 2.56 \\
\hline
\end{tabular}

Table 4 Summary of "if then else" functions

\begin{tabular}{cl}
\hline Variable & \multicolumn{1}{c}{ Table function } \\
\hline \multirow{2}{*}{ Rural residents living water-use coefficient } & If then else (Time $\leq 2001,0.043$, if then else (Time $>2001:$ and: Time $\leq 2009$, \\
& 0.05$, if then else (Time $>2009,0.065,0)$ ) \\
Urban residents living water-use coefficient & If then else (Time $\leq 2000,0.095$, if then else (Time $\geq 2001:$ and: Time $\leq 2009$, \\
& 0.106, if then else $($ Time $>2009,0.13,0)$ )) \\
Grape canal irrigation norm & If then else (Time $\leq 2009,700$, if then else (Time $>2009:$ and: Time $<2015$, \\
& 650$, if then else (Time $\geq 2015,600,0))$ ) \\
\hline
\end{tabular}

Note: These functions illustrate values during different time periods.

\subsection{Model calibration and validation}

This study encompasses a simulation length between 1990 and 2025 with records at annual intervals. The total simulation period considered here spans two stages, calibration and prediction. The first of these, the calibration stage, spans the period between 1990 and 2010, while the latter spans the period between 2011 and 2025, simulating future WCP under different scenarios.

Model calibration was conducted prior to analysis. In this step, simulation results were compared with actual historical data to verify the extent of their agreement as well as to assess the reliability of model parameters and the accuracy of the simulation model. Simulation results for total population (Fig. 9a) as well as for industrial and service industrial production (Figs. 9b and c) were compared with actual data. Records in Table 5 summarize comparisons between simulated and historical data for the period between 2006 and 2010; relative errors were considered acceptable when less than $5 \%$ absolute value (Table 5). Considering the randomness and variability of both the natural environment and social policy, these results suggest that our model is both valid and an effective simulation.
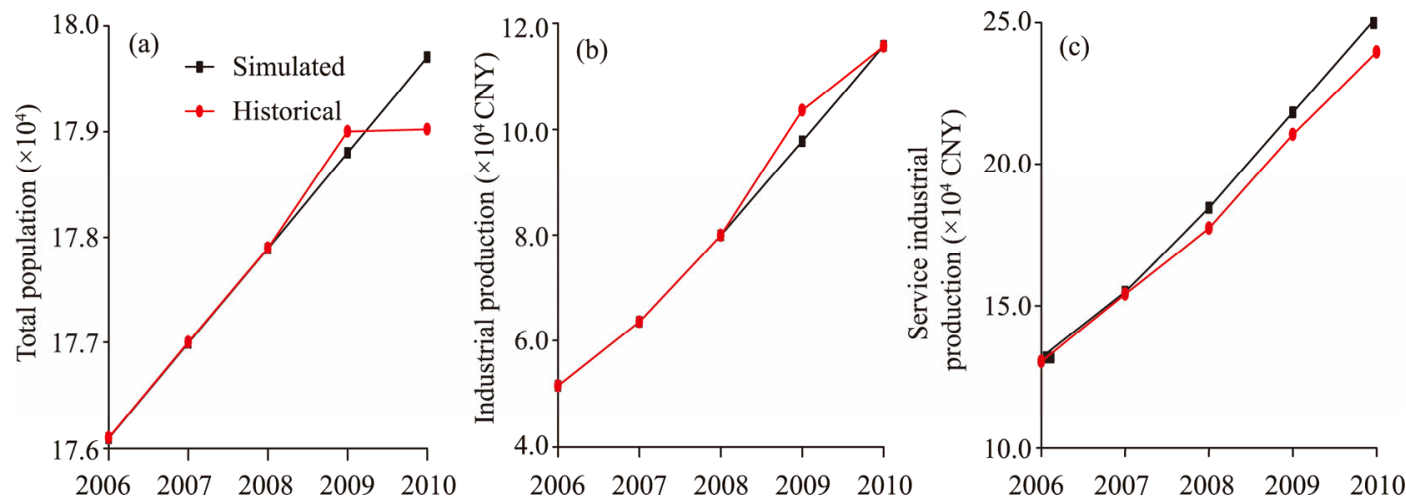

Fig. 9 Simulated results for total population (a), industrial production (b) and service industrial production (c)

\subsection{Scenario simulation}

Once the model had been calibrated, WCP scenario analysis was performed. Scenarios were constructed to both forecast and simulate potential changes in watershed management. The development of the Dunhuang Oasis depends on subsystem coordination, including population, 
environment, economic and ecological variables. In order to coordinate contradictions between resources, environmental and regional development provide the premise for the sustainable development of the Dunhuang Oasis. According to the local situations and actual needs, this paper simulates the WCP based on three scenarios, present-day as the baseline (Scenario 1), the watersaving/water-diversion condition (Scenario 2), and the ecological rehabilitation scenario (Scenario $3)$.

Table 5 Accuracy assessment of the simulated results

\begin{tabular}{cccc}
\hline \multirow{2}{*}{ Year } & \multicolumn{3}{c}{ Relative error (\%) } \\
\cline { 2 - 4 } & Total population & Industrial production & Service industrial production \\
\hline 2006 & 0.00 & -0.01 & 1.09 \\
2007 & 0.00 & -0.01 & 0.54 \\
2008 & 0.00 & -0.01 & 4.04 \\
2009 & -0.11 & -4.71 & 3.75 \\
2010 & 0.38 & -1.38 & 4.97 \\
\hline
\end{tabular}

Note: Yangguan Town was excluded from the statistical data presented. - , simulated value $<$ real value.

\subsubsection{Scenario 1}

This scenario, also known as the baseline, assumes that development policies and system structure do not exert a large adjustment on the forecasting period. The records in Table 6 include all functions as well as "if then else" operations within the system. Thus, considering current development states, regional restrictive factors and policy implications, this research assumes a moderate trend function in terms of parameters. Urbanization rate was set at $59.0 \%$ for 2015 and $65.0 \%$ for 2025 , while the industrial and service industrial water consumption decrease from 160.00 to 52.70 and 18.00 to $9.30 \mathrm{~m}^{3}$ per $10^{4} \mathrm{CNY}$, respectively, via the implementation of water-saving measures. Numerous functions exist within the agricultural subsystem given current trends, which can be divided into crop irrigated area proportion and irrigation norm. Subsequent to the beginning of 2010, food crop area ratio decreased sharply while the area of cash crops with high economic benefits has progressively increased (Table 6). Water-saving measures have developed slowly over time, and the primary pattern of irrigation has used traditional field canals. Advanced water-saving irrigation modes, such as micro-irrigation and greenhouse irrigation, only make up a smaller proportion.

\subsubsection{Scenario 2}

This setting was designed as an integrated agricultural water saving and water diversion scenario that enables a wider discussion of the integrated influence of the Dunhuang Oasis to the overall WCP.

As agriculture is the largest water consumer within the Dunhuang Oasis, the implementation of water-saving measures in this context will be both indispensable and effective. Three concrete agricultural water saving-measures are currently utilized including (1) reducing irrigated area and planting area by $3600 \mathrm{hm}^{2}$ till 2020; (2) maintaining current food crop area, reducing the area of planted cotton and expanding the area of crops with high economic benefits (i.e., grapes and fruit trees); and (3) implementing water saving irrigation across the entire oasis, particularly by transforming the traditional irrigation mode to canal irrigation and micro-irrigation.

Because of the water shortage caused by the agricultural water consumption, water saved by implementing water-saving measures will likely only maintain the water demand-supply balance under the current land use pattern and can hardly provide enough water for ecological services. In this context, the inter-basin water diversion project that encompasses the Sugan Lake Basin and the Danghe River Basin has been proposed to be developed over the next few years. This project plans to supply $0.835 \times 10^{8} \mathrm{~m}^{3}$ of water into the Dunhuang Oasis from the Sugan Lake Basin.

Analysis shows that the functions of agricultural and ecological subsystems will be modified under this scenario (Table 7) although remaining parameters will be the same as in Scenario 1. 
Table 6 Parameters and Scenario 1 values

\begin{tabular}{|c|c|c|c|c|}
\hline Parameter & 2010 & 2015 & 2020 & 2025 \\
\hline Population growth rate $(\%)$ & 5.10 & 5.10 & 5.10 & 5.10 \\
\hline Urbanization rate $(\%)$ & 50.00 & 59.00 & 65.00 & 65.00 \\
\hline Rural residents living water consumption $\left(\mathrm{m}^{3} / \mathrm{d}\right)$ & 65.00 & 65.00 & 65.00 & 65.00 \\
\hline Urban residents living water consumption $\left(\mathrm{m}^{3} / \mathrm{d}\right)$ & 130.00 & 130.00 & 130.00 & 130.00 \\
\hline Large livestock water consumption $\left(\mathrm{m}^{3} / \mathrm{d}\right)$ & 40.00 & 40.00 & 40.00 & 40.00 \\
\hline Small livestock water consumption $\left(\mathrm{m}^{3} / \mathrm{d}\right)$ & 10.00 & 10.00 & 10.00 & 10.00 \\
\hline Service industrial production growth rate $(\%)$ & 7.12 & 7.12 & 11.38 & 9.96 \\
\hline Service industrial water consumption $\left(\mathrm{m}^{3} /\left(\times 10^{4} \mathrm{CNY}\right)\right)$ & 14.00 & 11.30 & 9.30 & 9.30 \\
\hline Industrial production growth rate $(\%)$ & 7.50 & 8.70 & 9.40 & 10.50 \\
\hline Industrial water consumption $\left(\mathrm{m}^{3} /\left(\times 10^{4} \mathrm{CNY}\right)\right)$ & 100.00 & 63.90 & 52.70 & 52.70 \\
\hline irrigated area $\left(\times 10^{4} \mathrm{hm}^{2}\right)$ & 3.52 & 3.52 & 3.52 & 3.52 \\
\hline Food crop area proportion $(\%)$ & 0.31 & 0.31 & 0.31 & 0.31 \\
\hline Cotton crop area proportion $(\%)$ & 53.02 & 46.57 & 46.57 & 46.57 \\
\hline Grape area proportion $(\%)$ & 19.13 & 21.13 & 21.13 & 21.13 \\
\hline Melon area proportion $(\%)$ & 2.63 & 2.63 & 2.63 & 2.63 \\
\hline Fruit tree area proportion $(\%)$ & 9.25 & 13.70 & 13.70 & 13.70 \\
\hline Vegetable area proportion $(\%)$ & 13.66 & 13.66 & 13.66 & 13.66 \\
\hline Shelter forest area proportion $(\%)$ & 2.00 & 2.00 & 2.00 & 2.00 \\
\hline Food crop canal irrigation area proportion (\%) & 1.00 & 1.00 & 1.00 & 1.00 \\
\hline Cotton micro-irrigation area proportion $(\%)$ & 0.10 & 0.10 & 0.10 & 0.10 \\
\hline Cotton canal irrigation area proportion (\%) & 0.90 & 0.90 & 0.90 & 0.90 \\
\hline Vegetable canal irrigation area proportion (\%) & 0.91 & 0.91 & 0.91 & 0.91 \\
\hline Vegetable micro-irrigation area proportion (\%) & 0.04 & 0.04 & 0.04 & 0.04 \\
\hline Vegetable greenhouse micro-irrigation area proportion $(\%)$ & 0.05 & 0.05 & 0.05 & 0.05 \\
\hline Melon canal irrigation area proportion (\%) & 1.00 & 1.00 & 1.00 & 1.00 \\
\hline Grape canal irrigation area proportion (\%) & 0.98 & 0.98 & 0.98 & 0.98 \\
\hline Grape micro-irrigation area proportion (\%) & 0.02 & 0.02 & 0.02 & 0.02 \\
\hline Fruit trees canal irrigation area proportion $(\%)$ & 1.00 & 1.00 & 1.00 & 1.00 \\
\hline Shelter forest canal irrigation area proportion $(\%)$ & 1.00 & 1.00 & 1.00 & 1.00 \\
\hline Food crop irrigation norm $\left(\mathrm{m}^{3} / \mathrm{hm}^{2}\right)$ & 6150.00 & 6150.00 & 6150.00 & 6150.00 \\
\hline Cotton micro-irrigation norm $\left(\mathrm{m}^{3} / \mathrm{hm}^{2}\right)$ & 6750.00 & 6750.00 & 6750.00 & 6750.00 \\
\hline Cotton canal irrigation norm $\left(\mathrm{m}^{3} / \mathrm{hm}^{2}\right)$ & 8250.00 & 8250.00 & 8250.00 & 8250.00 \\
\hline Vegetable canal irrigation norm $\left(\mathrm{m}^{3} / \mathrm{hm}^{2}\right)$ & $10,200.00$ & $10,200.00$ & $10,200.00$ & $10,200.00$ \\
\hline Vegetable micro-irrigation norm $\left(\mathrm{m}^{3} / \mathrm{hm}^{2}\right)$ & 7200.00 & 7200.00 & 7200.00 & 7200.00 \\
\hline Vegetable greenhouse micro irrigation norm $\left(\mathrm{m}^{3} / \mathrm{hm}^{2}\right)$ & 6000.00 & 6000.00 & 6000.00 & 6000.00 \\
\hline Melon irrigation norm $\left(\mathrm{m}^{3} / \mathrm{hm}^{2}\right)$ & 8250.00 & 7800.00 & 7800.00 & 7800.00 \\
\hline Grape canal irrigation norm $\left(\mathrm{m}^{3} / \mathrm{hm}^{2}\right)$ & 9750.00 & 9750.00 & 9000.00 & 9000.00 \\
\hline Grape micro-irrigation norm $\left(\mathrm{m}^{3} / \mathrm{hm}^{2}\right)$ & 6750.00 & 6750.00 & 6750.00 & 6750.00 \\
\hline Shelter forest irrigation norm $\left(\mathrm{m}^{3} / \mathrm{hm}^{2}\right)$ & 6000.00 & 6000.00 & 6000.00 & 6000.00 \\
\hline Water diversion $\left(\times 10^{4} \mathrm{~m}^{3}\right)$ & 0.00 & 0.00 & 0.00 & 0.00 \\
\hline Flow into lower reaches $\left(\times 10^{4} \mathrm{~m}^{3}\right)$ & 4150.00 & 4150.00 & 4150.00 & 4150.00 \\
\hline Crescent Spring water demand $\left(\times 10^{4} \mathrm{~m}^{3}\right)$ & 600.00 & 600.00 & 600.00 & 600.00 \\
\hline Rural ecological water demand $\left(\times 10^{4} \mathrm{~m}^{3}\right)$ & 1677.00 & 1677.00 & 1677.00 & 1677.00 \\
\hline Urban ecological water demand $\left(\times 10^{4} \mathrm{~m}^{3}\right)$ & 300.00 & 300.00 & 300.00 & 300.00 \\
\hline
\end{tabular}

\subsubsection{Scenario 3}

This scenario comprises an ecological priority outcome that can be used to discuss how much irrigated land should be reclaimed to enable the ecological construction of the Dunhuang Oasis. 
The national water resource strategy research report "Water Resource Configuration, Ecological Environment Construction, and Strategy of Sustainable Development Research in Northwest China (Water Volume)" (Chen et al., 2004) puts forward the ecological rehabilitation and its implementation across Northwest China. This report states that the water supply required for an ecosystem should not be less than $50 \%$ of the total regional water consumption.

Based on Scenario 2, Scenario 3 uses the total water consumption of 2025 within the Dunhuang Oasis as the upper limit value in this ecological construction priority scenario. Thus, assuming that ecological water consumption is not less than $50 \%$ of the total water consumption, this analysis aims to determine how much irrigated land should be reduced, especially cash crops such as cotton, grapes and melon fields. This analysis does not take into account reductions in domestic and industrial water consumption because their proportions are so small.

Table 7 Scenario 2 parameters

\begin{tabular}{lrrrr}
\hline \multicolumn{1}{c}{ Parameter } & 2010 & 2015 & 2020 & 2025 \\
\hline Irrigated area $\left(\times 10^{4} \mathrm{hm}^{2}\right)$ & 3.52 & 3.40 & 3.28 & 3.18 \\
Cotton crop area proportion (\%) & 53.02 & 43.07 & 39.20 & 37.20 \\
Grape area proportion (\%) & 19.13 & 24.60 & 27.50 & 29.50 \\
Fruit trees area proportion (\%) & 9.25 & 13.70 & 14.70 & 14.70 \\
Cotton micro irrigation area proportion (\%) & 0.10 & 0.29 & 0.39 & 0.40 \\
Cotton canal irrigation area proportion (\%) & 0.90 & 0.71 & 0.61 & 0.60 \\
Vegetable canal irrigation area proportion (\%) & 0.71 & 0.27 & 0.23 & 0.23 \\
Vegetable micro-irrigation area proportion (\%) & 0.22 & 0.54 & 0.54 & 0.54 \\
Vegetable greenhouse micro-irrigation area proportion $(\%)$ & 0.07 & 0.19 & 0.23 & 0.23 \\
Grape canal irrigation area proportion (\%) & 0.80 & 0.43 & 0.40 & 0.40 \\
Grape micro irrigation area proportion $(\%)$ & 0.20 & 0.57 & 0.60 & 0.60 \\
Water diversion $\left(\times 10^{4} \mathrm{~m}^{3}\right)$ & 0.00 & 0.00 & 8350.00 & 8350.00 \\
Flow into lower reaches $\left(\times 10^{4} \mathrm{~m}^{3}\right)$ & 4150.00 & 4150.00 & 8500.00 & 8500.00 \\
Groundwater recharge $\left(\times 10^{4} \mathrm{~m}^{3}\right)$ & 0.00 & 0.00 & 4000.00 & 4000.00 \\
\hline
\end{tabular}

\section{Results and discussion}

\subsection{Scenario 1 WCP}

The Scenario 1 prediction for 2025 implies that the total population of the Dunhuang Oasis will reach up to $19.39 \times 10^{4}$; in this context, the urban population will increase from $9.40 \times 10^{4}$ in 2010 to $12.59 \times 10^{4}$ in 2025 because of the urbanization. At the same time, domestic water consumption within the study area is likely to increase rapidly from a volume of $6.49 \times 10^{6} \mathrm{~m}^{3}$ in 2010 to $7.54 \times 10^{6}$ $\mathrm{m}^{3}$ in 2025 . As a result of the booming tourism sector, the service industry is likely to consume almost $5.52 \times 10^{6} \mathrm{~m}^{3}$ of water in 2025 , while industrial water consumption will increase sharply from $10.88 \times 10^{6} \mathrm{~m}^{3}$ in 2010 to $22.60 \times 10^{6} \mathrm{~m}^{3}$ in 2025 .

Table 8 Dunhuang Oasis water consumption pattern under Scenario 1

\begin{tabular}{lrrrr}
\hline \multicolumn{1}{c}{ Parameter } & 2010 & 2015 & 2020 & 2025 \\
\hline Population $\left(\times 10^{4}\right)$ & 17.97 & 18.44 & 18.91 & 19.40 \\
Urban population $\left(\times 10^{4}\right)$ & 9.40 & 10.88 & 12.25 & 12.59 \\
Urban domestic water consumption $\left(\times 10^{6} \mathrm{~m}^{3}\right)$ & 4.46 & 5.16 & 5.81 & 5.97 \\
Rural domestic water consumption $\left(\times 10^{6} \mathrm{~m}^{3}\right)$ & 2.03 & 1.79 & 1.58 & 1.61 \\
Livestock water consumption $\left(\times 10^{6} \mathrm{~m}^{3}\right)$ & 2.25 & 2.46 & 2.68 & 2.92 \\
Industrial water consumption $\left(\times 10^{6} \mathrm{~m}^{3}\right)$ & 10.88 & 11.82 & 14.63 & 22.00 \\
Service industrial water consumption $\left(\times 10^{6} \mathrm{~m}^{3}\right)$ & 3.49 & 4.09 & 5.00 & 5.52 \\
Agricultural water consumption $\left(\times 10^{8} \mathrm{~m}^{3}\right)$ & 2.94 & 2.93 & 2.93 & 2.93 \\
Ecological water supply $\left(\times 10^{7} \mathrm{~m}^{3}\right)$ & 2.57 & 2.57 & 2.57 & 2.57 \\
Total water consumption $\left(\times 10^{8} \mathrm{~m}^{3}\right)$ & 3.43 & 3.44 & 3.48 & 3.55 \\
\hline
\end{tabular}


The volume of total available water within the Dunhuang Oasis is $4.02 \times 10^{8} \mathrm{~m}^{3}$; in this context, the average surface water supply is $3.02 \times 10^{8} \mathrm{~m}^{3}$ while groundwater exploitation within the irrigated area remains at a maximum of $1.00 \times 10^{8} \mathrm{~m}^{3}$. This means that a volume of $0.415 \times 10^{8} \mathrm{~m}^{3}$ must be removed from surface water to recharge the ecological system in the lower reaches, which would result in an ultimate usable surface water supply of $2.60 \times 10^{8} \mathrm{~m}^{3}$. The data presented in Table 8 summarize our SD simulation results. It is clear that total water consumption will increase from $3.43 \times 10^{8} \mathrm{~m}^{3}$ in 2010 to $3.55 \times 10^{8} \mathrm{~m}^{3}$ in 2025 . These results suggest that if this oasis is to be maintained at its current developmental state, high groundwater exploitation intensity is essential even though the problem of groundwater depletion has already become increasingly serious. The world-famous natural landscape of the Crescent Spring, for example, has experienced a water level decline of 9-11 $\mathrm{m}$ over the last 40 years such that part of the lake bottom is now exposed during the low-water season (Zhou et al., 2007). We conclude that Scenario 1 is therefore inconsistent with sustainable development.

\subsection{Scenario 2 WCP}

The two most important ways to save water from agricultural irrigation are reducing the area treated and implementing conservation measurements. Thus, if a target reduction of $3600 \mathrm{hm}^{2}$ can be attained, then the volume of agricultural water that can be saved will be large. Agricultural water consumption will decrease by $0.27 \times 10^{8} \mathrm{~m}^{3}$ given an average irrigation rate of $7500 \mathrm{~m}^{3} / \mathrm{hm}^{2}$. Subsequent to implementing water-saving measures and adjusting agricultural planting structures across the entire oasis, total agricultural water consumption is likely to decline significantly. The data summarized in Table 9 show that, compared to Scenario 1, the implementation of water-saving

Table 9 Water consumption pattern comparisons

\begin{tabular}{|c|c|c|c|}
\hline Variable & Year & Scenario 1 & Scenario 2 \\
\hline \multirow{4}{*}{ Total water consumption ${ }^{1}\left(\times 10^{8} \mathrm{~m}^{3}\right)$} & 2010 & 3.17 & 3.07 \\
\hline & 2015 & 3.18 & 2.84 \\
\hline & 2020 & 3.22 & 2.77 \\
\hline & 2025 & 3.31 & 2.78 \\
\hline \multirow{4}{*}{ Agricultural water consumption $\left(\times 10^{8} \mathrm{~m}^{3}\right)$} & 2010 & 2.94 & 2.84 \\
\hline & 2015 & 2.93 & 2.59 \\
\hline & 2020 & 2.93 & 2.47 \\
\hline & 2025 & 2.93 & 2.40 \\
\hline \multirow{4}{*}{ Agricultural water consumption (\%) } & 2010 & 92.70 & 92.50 \\
\hline & 2015 & 92.00 & 91.10 \\
\hline & 2020 & 90.70 & 89.20 \\
\hline & 2025 & 89.00 & 86.30 \\
\hline \multirow{4}{*}{$\begin{array}{l}\text { Total water consumption }{ }^{1}+\text { ecological water } \\
\text { supply }\left(\times 10^{8} \mathrm{~m}^{3}\right)\end{array}$} & 2010 & 3.43 & 3.32 \\
\hline & 2015 & 3.44 & 3.10 \\
\hline & 2020 & 3.48 & 3.86 \\
\hline & 2025 & 3.55 & 3.87 \\
\hline \multirow{4}{*}{ Ecological water supply $\left(\times 10^{7} \mathrm{~m}^{3}\right)$} & 2010 & 2.57 & 2.57 \\
\hline & 2015 & 2.57 & 2.57 \\
\hline & 2020 & 2.57 & 10.92 \\
\hline & 2025 & 2.57 & 10.92 \\
\hline \multirow{4}{*}{ Ecological water supply (\%) } & 2010 & 7.49 & 7.74 \\
\hline & 2015 & 7.47 & 8.29 \\
\hline & 2020 & 7.39 & 28.30 \\
\hline & 2025 & 7.24 & 28.20 \\
\hline
\end{tabular}

Note: Total water consumption ${ }^{1}=$ agricultural water subsystem+domestic water subsystem+industrial water subsystem + service water subsystem; agricultural water=agricultural water consumption/total water consumption ${ }^{1}$; ecological water=ecological water supply/(total water consumption ${ }^{1}+$ ecological water supply). 
measures within the Dunhuang Oasis are both very necessary and efficient as agricultural water consumption will decrease by almost $0.530 \times 108 \mathrm{~m} 3$. Agriculture remains the major consumer of water within the Dunhuang Oasis; thus, because of a large base, the proportion of total water consumption remains large. Models suggest that the proportion of water saved under Scenario 1 will be $89.0 \%$ in 2025 while under the water saving Scenario 2, this value will be $86.3 \%$ (Table 9) (i.e., in order to emphasize water-saving effects, ecological water supply was subtracted from the denominator of total water consumption (Table 2)). The agricultural water that will be saved under this scenario can be assigned to domestic and industrial subsystems and could also contribute to reduce a negative groundwater balance.

The additional water allocated from the inter-basin water diversion project also plays a very important role in alleviating the ecological water crisis within the oasis. Additional water diversion will increase ecological water supply in the oasis from $2.57 \times 10^{7}$ to $10.92 \times 10^{7} \mathrm{~m}^{3}$ while the ratio of ecological water supply will also increase significantly. At the same time, according to the DBP, groundwater exploitation will decrease from the current $10.0 \times 10^{7}$ to $6.80 \times 10^{7} \mathrm{~m}^{3}$ in the future. The increase of ecological water can recharge the groundwater level within the Dunhuang Oasis and improve the state of the lower reaches of West Lake Wetland.

\subsection{Scenario 3 WCP}

The ecological water supply under Scenario 2 is likely to reach a maximum volume of $10.9 \times 10^{7} \mathrm{~m}^{3}$ in 2025 while total water consumption is $3.87 \times 10^{8} \mathrm{~m}^{3}$. The assumption above states that the ecological water supply should not be less than $50 \%$ of total water consumption while the actual supply in this case should reach a goal of $1.94 \times 10^{8} \mathrm{~m}^{3}$ such that agricultural water consumption will be decreased by $0.84 \times 10^{8} \mathrm{~m}^{3}$. The results of our simulations show that if the overall proportions of crop structure remain unchanged, then total irrigated area will be decreased to $2.06 \times 10^{4} \mathrm{hm}^{2}$ by 2025 (Fig. 10). Areas of cotton, grapes, fruit trees and vegetables have also greatly decreased and play a critical role in Scenario 3 (Fig. 8).

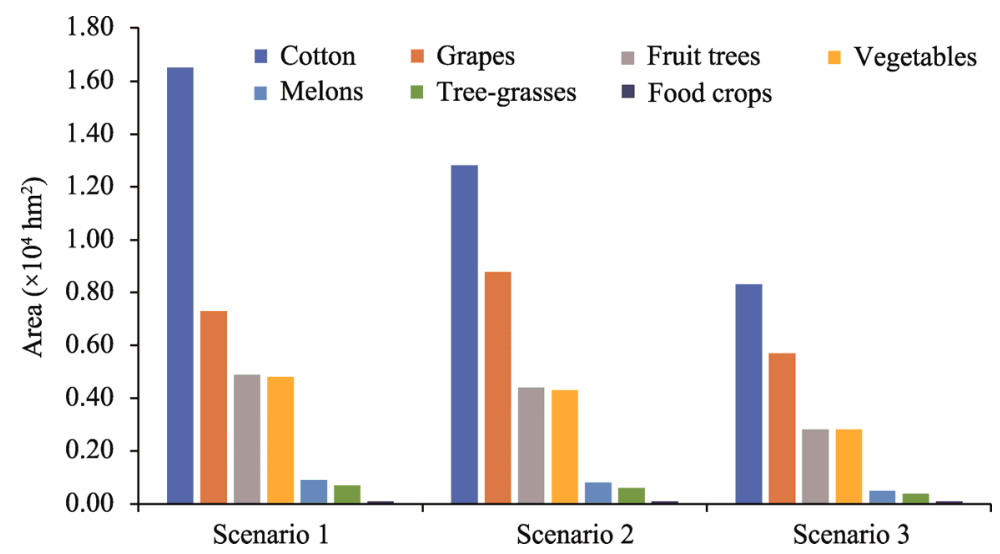

Fig. 10 Crop areas under the three scenarios

\section{Conclusions}

We analyzed WCP within the Dunhuang Oasis under three scenarios using a system dynamics model. The results of this study reveal that agriculture is the primary consumer of water within the Dunhuang Oasis $(>90 \%)$ while domestic, industrial and service industrial water consumption all together play a small role in Dunhuang Oasis WCP. As the total water consumption of these three accounted for $6.7 \%, 7.4 \%, 8.5 \%$ and $9.7 \%$ in 2010, 2015, 2020 and 2025, respectively, limited savings are likely to be found from these sections. Data show that under Scenario 1, the presentday baseline, total water consumption within the Dunhuang Oasis is likely to progressively increase as agricultural uses remain quite high. Depletion at this level will lead to worsening groundwater losses and will threaten the ecological security of the oasis. Modeling results suggest that implementing water-saving measures will lead to savings of almost $5.30 \times 10^{7} \mathrm{~m}^{3}$. A substantial 
agricultural base will lead to large total water consumption; thus, by 2025 , the proportion of water consumed by agriculture will decrease by only $2.7 \%$ from $89.0 \%$ under Scenario 1 to $86.3 \%$ under Scenario 2. The implementation of water-saving measures cannot be ignored; agricultural water saved in this way can be re-assigned to the domestic and industrial subsystems and can also contribute to mitigating groundwater depletion. The additional water supply available from the inter-basin diversion project will increase ecological water demand from $2.57 \times 10^{7}$ to $10.92 \times 10^{7} \mathrm{~m}^{3}$ while the water supply in this regard will also increase significantly. Additional water allocated from the inter-basin water diversion project will also play a very important role in alleviating the oasis ecological water crisis. Thus, if regional ecological construction is regarded as the most important development strategy within the Dunhuang Oasis, total irrigated area should be decreased to $2.06 \times 10^{4} \mathrm{hm}^{2}$ by 2025 .

\section{Acknowledgements}

This research was supported by the National Nature Science Foundation of China (41701321), the Fundamental Research Funds for the Central Universities (2662015QD031), and the 2014 Key Research Support Program of Central Government Higher Education Basic Research Founding (lzujbky-2014-269). The authors greatly appreciate Water Resource Management Bureau of Danghe River Basin of Jiuquan City for providing valuable meteorological data. We thank the Dunhuang Meteorological Station for providing the meteorological data. We would like to thank anonymous reviewers. We also thank the editors for their continued help during the revisions of the paper.

\section{References}

Bark R H, Peeters L J M, Lester R E, et al. 2013. Understanding the sources of uncertainty to reduce the risks of undesirable outcomes in large-scale freshwater ecosystem restoration projects: An example from the Murray-Darling Basin, Australia. Environmental Science \& Policy, 33: 97-108.

Berbel J, Gutiérrez-Martín C, Rodríguez-Díaz J A, et al. 2015. Literature review on rebound effect of water saving measures and analysis of a Spanish case study. Water Resources Management, 29(3): 663-678.

Bureau of Statistics of the City of Dunhuang. 2007. Dunhuang National Economic Statistics Yearbook. Dunhuang: Bureau of Statistics of the City of Dunhuang. (in Chinese)

Bureau of Statistics of the City of Dunhuang. 2013. Dunhuang National Economic Statistics Yearbook. Dunhuang: Bureau of Statistics of the City of Dunhuang. (in Chinese)

Burke T. 2012. Proposed Basin Plan, Water Act 2007. Canberra: Murray-Darling Basin Authority Press, 1-245.

Chen Z K, Wang H, Wang D X. 2004. Water Resource Configuration, Ecological Environment Construction and Strategy of Sustainable Development Research in Northwest China (Water Volume). Beijing: Science Press, 1-231. (in Chinese)

Cheng G D, Li X, Zhao W Z, et al. 2014. Integrated study of the water-ecosystem-economy in the Heihe River Basin. National Science Review, 1(3): 413-428.

Crase L, Pagan P, Dollery B. 2004. Water markets as a vehicle for reforming water resource allocation in the Murray-Darling Basin of Australia. Water Resource Research, 40(8): W08S05, doi: 10.1029/2003WR002786.

de Fraiture C, Molden D, Wichelns D. 2010. Investing in water for food, ecosystems, and livelihoods: An overview of the comprehensive assessment of water management in agriculture. Agricultural Water Management, 97(4): 495-501.

Department of Geoscience, Chinese Academy of Sciences. 1996. Water resource survey report in arid regions of northwest China. Advances in Earth Science, 11: 1-4. (in Chinese)

Feng Q, Endo K N, Cheng G D. 2001. Towards sustainable development of the environmentally degraded arid rivers of Chinaa case study from Tarim River. Environmental Geology, 41(1-2): 229-238.

Forrester J W. 1961. Industrial Dynamics. Cambridge: Massachusetts Institute of Technology Press, 1-484.

Gansu Province Water Conservancy and Hydropower Investigation and Design Institute. 2011. Field water-saving transformation project preliminary design report of Dang river irrigation district. Lanzhou, China. (in Chinese)

Gertseva V V, Schindler J E, Gertsev V I, et al. 2004. A simulation model of the dynamics of aquatic macroinvertebrate communities. Ecological Modelling, 176(1-2): 173-186.

Gutiérrez-Martín C, Borrego-Marín M M, Berbel J. 2017. The economic analysis of water use in the water framework directive based on the system of environmental-economic accounting for water: A case study of the Guadalquivir River Basin. Water, 9(3): 180, doi: 10.3390/w9030180. 
Higgins S I, Turpie J K, Costanza R, et al. 1997. An ecological economic simulation model of mountain fynbos ecosystems: Dynamics, valuation and management. Ecological Economics, 22(2): 155-169.

Hu R J, Jiang F Q, Wang Y J. 2010. To have a correct understanding of the stability of oasis in arid lands of China. Arid Zone Research, 27(3): 319-323. (in Chinese)

Hu X L, Lu L, Li X, et al. 2015a. Ejin oasis land use and vegetation change between 2000 and 2011: The role of the ecological water diversion project. Energies, 8(7): 7040-7057.

Hu X L, Lu L, Li X, et al. 2015b. Land use/cover change in the middle reaches of the Heihe River Basin over 2000-2011 and its implications for sustainable water resource management. PloS ONE, 10(6): e0128960.

Huang Q, He C, Shi P, et al. 2009. Modeling water resource carrying capacity change under stress of drought and socioeconomic development in Beijing. Journal of Natural Resources, 24(5): 859-870.

Ling $\mathrm{H}, \mathrm{Xu} \mathrm{H}, \mathrm{Fu}$ J, et al. 2013. Suitable oasis scale in a typical continental river basin in an arid region of China: A case study of the Manas River Basin. Quaternary International, 286: 116-125.

Micklin P P. 1988. Desiccation of the Aral Sea: a water management disaster in the Soviet Union. Science, 241(4870): 11701176.

Mohapatra P K, Mandal P, Bora M C. 1994. Introduction to System Dynamics Modeling. Hyderabad: Orient Longman Ltd Press, $1-608$.

Niu S W, Liu J L, Ma L, et al. 2010. Water resource carrying capacity along the Yellow River of Gansu Province. China Rural Water and Hydropower, 6: 20-25. (in Chinese)

Okin G S, Gillette D A, Herrick J E. 2006. Multi-scale controls on and consequences of aeolian processes in landscape change in arid and semi-arid environments. Journal of Arid Environments, 65(2): 253-275.

Qi S Z, Luo F. 2006. Land-use change and its environmental impact in the Heihe River Basin, arid northwestern China. Environmental Geology, 50(4): 535-540.

Sun Z, Chang N B, Opp C, et al. 2011. Evaluation of ecological restoration through vegetation patterns in the lower Tarim River, China with MODIS NDVI data. Ecological Informatics, 6(2): 156-163.

Water Resources Department of Gansu Province. 2005. Industry Water Use Quota of Gansu Province. Lanzhou: Gansu People's Publishing House Press, 1-38. (in Chinese)

Water Resource Department of Gansu Province. 2011. Comprehensive planning of rational use of water resource and protection of ecosystem services in the Dunhuang Region. Lanzhou: Gansu People's Publishing House Press, 1-75. (in Chinese)

Wheeler S, Loch A, Zuo A, et al. 2014. Reviewing the adoption and impact of water markets in the Murray-Darling Basin, Australia. Journal of Hydrology, 518: 28-41.

Woodhouse C A, Gray S T, Meko D M. 2006. Updated streamflow reconstructions for the Upper Colorado River basin. Water Resources Research, 42(5): 648.

Zhang X F, Zhang L H, He C S, et al. 2014. Quantifying the impacts of land use/land cover change on groundwater depletion in Northwestern China-A case study of the Dunhuang oasis. Agricultural Water Management, 146: 270-279.

Zhao C H, Wang P, Zhang G H. 2015. A comparison of integrated river basin management strategies: A global perspective. Physics and Chemistry of the Earth, Parts A/B/C, 89-90: 10-17.

Zhou C J, Dong S C, Li D, et al. 2007. The characteristics and sustainable utilization of water resource in Dunhuang City of Gansu Province, China. Journal of Natural Resources, 22(4): 516-523. (in Chinese)

Zhu Q, Li Y. 2014. Environmental restoration in the Shiyang River Basin, China: conservation, reallocation and more efficient use of water. Aquatic Procedia, 2: 24-34. 